\title{
CRIMINAL PUnishment Without Civil Rights: THE CRIMINAL PROCEEDS AND INSTRUMENTS BILL'S Punitive CIVIL SANCTIONS
}

\author{
Peter Wright ${ }^{*}$
}

This article critiques the Criminal Proceeds and Instruments Bill 2005 which introduces a civil forfeiture regime for the proceeds of serious criminal offending. By using a civil forfeiture regime, many of the protections normally granted to criminal defendants are not available, which makes successful action by the State easier. This article argues that the Bill's civil forfeiture regime risks seriously abrogating individuals' rights, including those arising from the requirement for proof beyond a reasonable doubt and the prohibitions on double jeopardy and retrospective punishment. The article concludes that the confiscation of criminals' assets should take place within the criminal justice system to ensure that there are proper protections for defendants.

\section{INTRODUCTION}

This Bill does not breach at all the principles of justice.... What we are doing in this Bill is not getting a criminal conviction that will allow us to deprive a person of liberty; we would do that if we had the standard of proof for that. Under this Bill it must be demonstrated that, on the civil standard of proof, this property has been wrongly acquired by the individual, does not belong to the individual, and should be taken over by the State. That does not breach the New Zealand Bill of Rights Act or any other principle of justice. ${ }^{1}$

The Criminal Proceeds and Instruments Bill 2005 ("CPIB") is a legislative attempt to deal with organised crime and drug dealing. The CPIB operates by reducing the pecuniary benefits that accrue to offenders as a result of certain serious criminal activities. The principle feature of the CPIB is the introduction of a civil forfeiture regime for the proceeds of crime. Defendants may have their property confiscated without having been convicted of a criminal offence, entirely outside the

* Submitted as part of the LLB(Hons) programme at Victoria University of Wellington.

1 Hon Phil Goff, Minister of Justice (12 December 2004) 622 NZPD 17296. 
criminal justice process. Prosecutors merely need to show that it is more likely than not that the defendant has profited from criminal offending.

The New Zealand Bill of Rights Act 1990 ("NZBORA") gives significantly fewer procedural protections to defendants in civil proceedings than to defendants in criminal proceedings. The CPIB takes advantage of this by using civil proceedings to tackle organised crime and drug dealing, activities normally dealt with by the criminal law. This means that despite the severe impact upon defendants, the civil forfeiture regime does not breach the NZBORA. I argue, however, that it does breach the "principles of justice" referred to by the Minister of Justice.

This article therefore begins by introducing the CPIB. It then introduces Kenneth Mann's theory of punitive civil sanctions. ${ }^{2}$ The civil forfeiture regime contained within the CPIB is identified as a punitive civil sanction: a sanction which is classified for the purposes of NZBORA protections as part of a civil proceeding, but which is criminal in substance and has a punitive effect. The civil forfeiture regime contained in the CPIB undertakes what is in substance a function of the criminal law. It is not constrained by the obstacles normally imposed upon criminal proceedings, such as the requirement for proof beyond a reasonable doubt, and the prohibitions on double jeopardy and retrospective punishment.

I argue that it is inappropriate to use punitive civil sanctions to deal with the most serious criminal offences, such as organised crime and drug dealing. The severe punishments required to deal effectively with the offending necessitate strong procedural protections to ensure their fair application. The lower level of severity in dealing with the offending, by using civil forfeiture rather than criminal prosecution in order to avoid the application of the NZBORA protections, may mean that the offending is not effectively dealt with. Depriving criminal offenders of any profits of their offending is essential to deter future offending, but forfeiture should be carried out within the criminal justice process. This will result in greater effectiveness in preventing and punishing criminal offending, and will provide proper procedural protections to defendants.

The CPIB signals a failure in "striking the right balance between the necessary law enforcement priorities and [protecting] the legitimate rights of defendants ... from unreasonable State action."3 The procedural protections provided to defendants in the CPIB are insufficient to adequately protect a defendant who is in substance facing a criminal sanction. This article concludes with an examination of the proposals made to the Government by the Ministry of Justice for reform of the

2 Kenneth Mann "Punitive Civil Sanctions: The Middleground between Criminal and Civil Law" (1992) 101 Yale LJ 1795.

3 Ministry of Justice Proceeds of Crime Act 1991: Review of Operational Effectiveness (Wellington, 2003) 1 (Obtained under Official Information Act 1982 Request to the Ministry of Justice). 
Proceeds of Crime Act 1991 ("PCA"). ${ }^{4}$ I recommend that the civil forfeiture regime contained in the CPIB be abandoned, with confiscation of the proceeds of crime to be undertaken only within the criminal justice system.

\section{THE CRIMINAL PROCEEDS AND INSTRUMENTS BILL 2005}

\section{A Rationale for Forfeiture of the Proceeds of Crime}

The rationale for proceeds of crime legislation is six-fold: ${ }^{5}$

- $\quad$ to deter crime by reducing actual and expected profitability;

- to prevent crime by diminishing the capacity of offenders to finance further criminal activity;

- $\quad$ to redress the unjust enrichment of those who profit at society's expense;

- to compensate society for the harm, suffering and human misery caused by crime;

- to reimburse the State for the ever increasing cost of fighting crime; and

- to engender public confidence in the administration of justice by demonstrating that crime does not pay.

These reasons justify the various legislative approaches taken around the common law world to the confiscation of the proceeds of crime. Confiscation allows courts to overcome the problem faced when tackling crime which has resulted in a high pecuniary benefit to the offender. Fines are determined by reference to an individual's culpability, ability to pay and statutory limits, rather than by the value of the profits of the crime, often leaving the defendant or their family with the fruits of crime to enjoy then or later. ${ }^{6}$

In New Zealand, stolen property, or property that is illegal to possess, has always been confiscated as part of the criminal process, but if the criminal activity created a profit for the offenders, the recovery by the State of this profit was difficult. Dedicated legislation for the confiscation of the proceeds and instruments of crime was introduced in New Zealand in response to the United Nations Convention against Illicit Traffic in Narcotic Drugs and Psychotropic

4 Warren Young, Deputy Secretary Crime Prevention and Criminal Justice, to the Minister of Justice "Proceeds of Crime" (6 November 2003) Letter (Obtained under Official Information Act 1982 Request to the Ministry of Justice).

5 David Lusty "Civil Forfeiture of the Proceeds of Crime in Australia" (2002) 5 Journal of Money Laundering Control 345, 345 .

6 David Feldman Criminal Confiscation Orders - The New Law (Butterworths, London, 1988) 1. 
Substances, ${ }^{7}$ which required States to take action against organised crime. New Zealand's response to the convention, the PCA, was introduced at a time of growing unease about the profitability of both traditional organised crime, ${ }^{8}$ and the white collar crime which marked the late 1980s. ${ }^{9}$ Based upon the equivalent Australian legislation, the Proceeds of Crime Act 1987 (Cth), it was part of a package of legislation introduced to deal with the unique problems faced by law enforcement in dealing with organised crime. ${ }^{10}$

\section{B Failure of the Proceeds of Crime Act 1991}

Initially the reception of the PCA was positive, ${ }^{11}$ but by the late 1990 s there was disquiet at the lack of success of the PCA in achieving significant confiscation of criminal assets. ${ }^{12}$ The PCA only resulted in the recovery of $\$ 14,200,000$ between 1991 and $2003,{ }^{13}$ significantly below the levels initially envisaged. ${ }^{14}$ This was arguably due to the difficulty in securing convictions against the leaders of organised crime groups, who were difficult to successfully prosecute, ${ }^{15}$ and the fact that confiscation under the PCA is only possible where there has been a criminal conviction. Additionally, the required evidentiary link between criminal activity and the particular property acquired meant that usually only the instruments of crime, rather than the proceeds of crime, were successfully confiscated under the PCA. ${ }^{16}$ In cases where an individual has a large amount of unexplained property or income and is suspected of having obtained it through criminal offending, the PCA is ineffective unless there is sufficient evidence to convict them of a criminal offence.

A further indication of the limited usefulness of the PCA was its inability to reduce the power of organised crime in New Zealand, as illustrated by the increased supply of methamphetamine. The

7 United Nations Convention against Illicit Traffic in Narcotic Drugs and Psychotropic Substances (20 December 1988) 28 ILM 493.

$8 \quad$ (4 September 1990) 510 NZPD 4303.

$9 \quad$ (4 September 1990) 510 NZPD 4309.

10 This includes: Mutual Assistance in Criminal Matters Act 1991; Crimes Act 1961, s 257A; Misuse of Drugs Act 1975, s 12B; and the Financial Transactions Reporting Act 1996. See Robert Lithgow "The Proceeds of Crime Act 1991: Does It Work, 10 Years On?" (New Zealand Law Society Criminal Law Symposium, Wellington, 8 November 2002) 6

11 "Making Sure Crime Does Not Pay" (19 February 1993) New Zealand Herald Auckland 10; "Law Adds New Weapon to Drug Swoop" (12 October 1994) The Dominion Wellington 2.

12 "Gangs High on Police Agenda" (14 October 1999) The Dominion Wellington 2; Steven Marks "Nats Promise Tighter Squeeze on Criminals" (13 October 1999) The Evening Post Wellington 1.

13 Young, above n 4, 3.

14 Young, above n 4, 5.

15 Young, above n 4, 5.

16 Young, above n 4, 7. 
PCA was also ineffective in tackling the rise of organised crime groups as they developed new networks for the distribution and supply of methamphetamine. With the illicit methamphetamine market worth an estimated $\$ 98,000,000$ in $2004,{ }^{17}$ the trade, which is largely controlled by organised crime, gives such groups a significant economic boost. ${ }^{18}$ This economic support has allowed organised crime groups to "insulate [themselves] from enforcement pressure, raise [their] prestige, thereby enhancing [their] ability to attract new members, and [it] provides the monetary funds necessary to seek to influence and corrupt governance agencies and processes." 19

This represents one of the greatest fears associated with the continued economic success of organised crime. The Police have made alarming claims that, as in overseas jurisdictions, increased economic power of organised crime can lead to juror intimidation, police corruption and assassinations of law enforcement and judicial officials, all undermining the justice system. ${ }^{20}$ Serious criminal offending by users of the drug, including several infamous murders, has led to renewed attention by the government on the effects of methamphetamine on society and public safety. ${ }^{21}$ The Police argue that reduction in the resources of organised crime would result in a net drop in the sale and manufacture of methamphetamine. ${ }^{22}$

There are, however, inherent problems with tackling criminal offending through the asset base of offenders. Well-resourced offenders are able to reorganise their ownership structures to avoid the effect of any confiscation legislation. For instance, organised crime groups can "move assets offshore, rent rather than buy clubrooms and set up complex trusts to hide their wealth in legitimate businesses." 23 With the help of skilled advisors, leaders of organised crime groups are able to take advantage of measures designed to protect third parties. The failure of the PCA to deal with organised crime and the growing use of methamphetamine led to discussion for reform of the PCA from 1997, and a full review of the PCA by the Ministry of Justice in late $2003 .^{24}$

17 Chris Wilkins and others The Socio-Economic Impact of Amphetamine Type Stimulants in New Zealand (Massey University, Auckland, 2004) 63.

18 "How Organised Crime Controls the Meth Market" (January/February 2005) Police News 12.

19 Wilkins and others, above n 17, 57.

20 "Hitting at the Heart of the Justice System" (January/February 2005) Police News 15.

21 Sonti Chalpat "What's Happening" (11 June 2005) The Dominion Post Wellington 8.

22 Wilkins and others, above n 17, 106.

23 "Gangs Will Adapt Quickly to Circumvent Asset Seizure Laws" (January/February 2005) Police News 15.

24 Ministry of Justice, above n 3. 


\section{Principal Features of the Criminal Proceeds and Instruments Bill 2005}

The Ministry of Justice initially made recommendations for the reform of the PCA to make it operate more effectively. ${ }^{25}$ However, these proposals were rejected by the Minister and, against the Ministry's advice, he requested development of a proposal for a radical reform of the PCA, including the introduction of a civil forfeiture regime. Proposals for such a regime were developed, ${ }^{26}$ and by March 2004 Cabinet agreed upon civil forfeiture as a desirable approach. ${ }^{27}$ The CPIB was introduced to Parliament on 21 June 2005. The Minister of Justice identified organised crime as the clear target of the $\mathrm{CPIB},{ }^{28}$ just as his predecessor had done 15 years ago with the PCA. ${ }^{29}$ The CPIB would replace the PCA as the principal statute for the forfeiture of the proceeds of crime.

The existence of serious criminal offending is a prerequisite for the operation of the provisions of the CPIB, as with the PCA. Like the PCA, there are interim measures available under the CPIB to avoid the dispersal of assets prior to the hearing of a case. There are two separate mechanisms contained within the CPIB. First, there is a conviction-based confiscation mechanism for the instruments of crime, whereby there are powers to order confiscation under amendments to the Sentencing Act 2002. This is fundamentally the same as the current operation of the PCA, in that it operates post-conviction. Secondly, there is the introduction of a non-conviction-based civil forfeiture regime for the proceeds of crime. The fundamental difference between civil and criminal forfeiture is that civil forfeiture does not require a criminal conviction as a prerequisite for confiscation.

\section{Threshold for operation}

For the confiscation mechanisms of the CPIB to operate there must have been significant criminal activity, defined as an offence punishable by imprisonment for five or more years or a fine of $\$ 30,000$ or more. ${ }^{30}$ It covers many offences associated with organised crime, including dealing

25 Young, above $\mathrm{n} 4$.

26 Warren Young, Deputy Secretary Crime Prevention and Criminal Justice, to the Minister of Justice "Proceeds of Crime" (11 March 2004) Letter (Obtained under Official Information Act 1982 Request to the Ministry of Justice).

27 Cabinet Minute "Additional Item: Proceeds of Crime: Development of a Civil Forfeiture Regime" (15 March 2004) CAB Min (04) 8/18 (Obtained under Official Information Act 1982 Request to the Ministry of Justice).

28 Minister of Justice "New Bill Will Reap Millions From Gangs" (21 June 2005) Press Release.

29 (4 September 1990) 510 NZPD 4303.

30 Criminal Proceeds and Instruments Bill 2005, no 279-1, cl 5. 
with controlled drugs, ${ }^{31}$ people smuggling offences, ${ }^{32}$ corruption and bribery, ${ }^{33}$ robbery ${ }^{34}$ and kidnapping. ${ }^{35}$ These are all offences which can result in a high pecuniary benefit for offenders. This is the same threshold as under the PCA. ${ }^{36}$

\section{Restraining orders}

Restraining orders act as a temporary restriction upon the assets to avoid their dispersal pending a full forfeiture order by the court, and can be made ex parte. ${ }^{37}$ Assets are taken into the custody and control of the Official Assignee. For the court to grant a restraining order for an "Instrument Forfeiture Order", the Director of Criminal Proceeds Confiscation ("the Director") or the prosecutor of a criminal proceeding must show that there is currently, or that there are reasonable grounds to believe that there will be, a prosecution for serious criminal offending. Under the civil forfeiture regime, by contrast, a restraining order will be granted to the Director if it is shown that there is a reasonable belief that property has been acquired from significant criminal activity or the defendant has profited from significant criminal activity. Restraining orders are deemed to be undertaken as part of civil proceedings under the CPIB, but their ultimate classification will depend on the subsequent substantive order.

\section{Criminal forfeiture}

The forfeiture of the instruments of crime is handled under amendments to the Sentencing Act 2002. Under the inserted section $142 \mathrm{M}$, the court can confiscate property used in the facilitation of a qualifying offence, being an offence punishable by five or more years in prison. As under the PCA, an Instrument Forfeiture Order is a criminal forfeiture and will require a criminal conviction. ${ }^{38}$ This feature is the key difference from the Criminal Assets Recovery Act 1990 (NSW), under which instruments and proceeds of crime are not viewed separately. At sentencing under the CPIB, the judge can consider the forfeiture of the instruments to avoid disproportionate punishment for offenders who used valuable assets in their offending, a key criticism of the operation of the PCA. ${ }^{39}$

\footnotetext{
31 Misuse of Drugs Act 1975, s 6.

32 Crimes Act 1961, ss 98C-98D.

33 Crimes Act 1961, ss 101-105.

34 Crimes Act 1961, ss 234-235.

35 Crimes Act 1961, s 209.

36 Proceeds of Crime Act 1991, ss 2 and 7.

37 Criminal Proceeds and Instruments Bill 2005, no 279-1, cls 24-26.

38 Criminal Proceeds and Instruments Bill 2005, no 279-1, cl 10(2).

39 See Louise Moreland "Justice in Jeopardy: The Relationship between Sentencing and Confiscation Orders under the Proceeds of Crime Act 1991" (2000) 31 VUWLR 497.
} 
Criminal forfeiture proceedings may be undertaken by either the Director or the prosecutor of the criminal proceeding.

\section{Civil forfeiture}

Civil forfeiture under the CPIB occurs following the granting of an "Asset Forfeiture Order" or a "Profit Forfeiture Order". ${ }^{40}$ There is no requirement that there be any criminal prosecution for these actions to succeed. Civil forfeiture proceedings may only be undertaken by the Director.

Profit Forfeiture Orders are made against the defendant for a monetary amount. The Director must prove on the balance of probabilities that the defendant has profited from significant criminal activity in the previous seven years, and state a claimed amount. The burden is then placed upon the defendant to prove that the amount claimed is too great. The rationale for this is that it is easier for the defendant to prove that income has been derived legally than for the Director to show that it has not. This responds to a core complaint of the Police regarding the operation of the PCA and the difficulty in proving a link between specific assets and specific criminal offences. ${ }^{41}$

Asset Forfeiture Orders will be granted where it is shown on the balance of probabilities that the property is derived from significant criminal activity. ${ }^{42}$ Once the link between the defendant and serious criminal offending has been made, any assets that the defendant owns could be confiscated. This could include assets lawfully acquired if they were purchased using money earned through criminal offending.

The civil forfeiture regime contained in the CPIB represents the use of an order made in a civil proceeding to achieve objectives normally reserved for the criminal law. The different procedures followed in criminal and civil proceedings represent the inherently different values underpinning them. Using a mechanism classified as a civil proceeding to achieve the criminal law objective of tackling organised crime potentially introduces a number of problems. Under the common law and statute there have always been special protections granted to defendants in criminal proceedings over and above those granted to defendants in civil proceedings. These will not be extended to defendants of civil forfeiture under the CPIB. The drafters of the CPIB ease the process by which the State can impose sanctions upon organised crime syndicates and drug dealers by using a civil classification to circumvent many of the protections that defendants in criminal proceedings would normally be afforded.

40 Criminal Proceeds and Instruments Bill 2005, no 279-1, cl 10(1).

41 Young, above n 4, 7.

42 Criminal Proceeds and Instruments Bill 2005, no 279-1, cl 47. 


\section{PUNITIVE CIVIL SANCTIONS}

\section{A A Definition of Punitive Civil Sanctions}

Civil forfeiture under the CPIB is undertaken in a civil setting, not a criminal one, despite its objective of controlling crime. Traditionally, conceptions of law are based upon a clear division between criminal and civil law, but the increasing crossover between the two areas has blurred the distinction. Punitive civil sanctions are those sanctions which occupy the area between the criminal and civil law. The principal advantage, from the State's perspective, is that punitive civil sanctions do not engage the special procedural protections for criminal defendants contained in sections 24 to 26 of the NZBORA.

The division between civil and criminal law is based upon the notion that the civil law compensates, while the criminal law punishes. Punitive civil sanctions, however, punish civilly, ${ }^{43}$ and they possess characteristics of both the civil and criminal law. Mann identifies the key elements of the civil and criminal law in the following way: ${ }^{44}$

\begin{tabular}{|lll|}
\hline & $\begin{array}{l}\text { CRIMINAL } \\
\text { PARADIGM }\end{array}$ & $\begin{array}{l}\text { CIVIL } \\
\text { PARADIGM }\end{array}$ \\
\hline PLAINTIFF & State & Private entity \\
PROCEDURE & $\begin{array}{l}\text { Subjective liability; violation } \\
\text { of public norms }\end{array}$ & $\begin{array}{l}\text { Objective liability; actual } \\
\text { injury to private interests }\end{array}$ \\
REMEDY & High burden of proof & Low burden of proof \\
PURPOSE & Imprisonment; stigma & Money payment; injunction \\
\hline
\end{tabular}

Punitive civil sanctions are ones which largely fit within the civil paradigm, except that they punish, rather than compensate. Exemplary damages in tort is the most obvious type of punitive civil sanction; despite mostly fitting into the civil paradigm, the purpose of exemplary damages is to punish the tortfeasor. ${ }^{45}$ Aside from exemplary damages, however, most punitive civil sanctions are imposed where the State is the plaintiff. ${ }^{46}$

\footnotetext{
43 Mann, above n 2, 1798.

44 Mann, above n 2, 1813.

45 See generally Taylor v Beere [1982] 1 NZLR 81 (CA).

46 Mann, above n 2, 1847.
} 
While Mann's theory of punitive civil sanctions by no means provides a complete explanation of the CPIB, it does serve as a useful framework for examining the new forfeiture procedures contained in the CPIB. If the CPIB is a punitive civil sanction, then Mann's commentary on why punitive civil sanctions are employed and when it is appropriate for legislatures to use them is highly relevant.

\section{B Categorising Civil Forfeiture}

Under the NZBORA, special protections are granted to defendants who have been charged with an offence. In the "widely accepted"47 test of the Supreme Court of Canada in $R v$ Wigglesworth, ${ }^{48}$ two possible definitions of "charged with an offence" were offered. First, the proceeding could be "of a public nature, intended to promote public order and welfare within a public sphere of activity." 49 The second definition requires that there be "true penal consequences" for the defendant as a result of the proceeding. ${ }^{50}$

The CPIB contains a purpose clause which excludes punishment, focusing instead on deterrence and the reduction of benefits to offenders. ${ }^{51}$ The CPIB avoids the language commonly used in the criminal law. Terms such as guilt, conviction and punishment are absent.

The stated philosophical basis of civil forfeiture is restitution and unjust enrichment, not punishment, ${ }^{52}$ with the Australian Law Reform Commission considering the relationship between confiscating the proceeds of crime and conviction as: ${ }^{53}$

... rooted in a broader concept that no person should be entitled to be unjustly enriched from any unlawful conduct, criminal or otherwise, [so that] conviction of a criminal offence could properly be seen as but one circumstance justifying forfeiture rather than as the single precipitating circumstance for recovery of unjust enrichment.

The Court of Appeal considered the purpose of the CPIB's predecessor, the PCA, in $R v$ Brough. ${ }^{54}$ The Court decided that the confiscation of profits from criminal activity under the PCA

47 Rishworth and others The New Zealand Bill of Rights (Oxford University Press, Auckland, 2003) 585.

$48 \quad R v$ Wigglesworth [1987] 2 SCR 541 [Wigglesworth].

49 Wigglesworth, above n 48, 560 Wilson J.

50 Wigglesworth, above n 48, 559 Wilson J.

51 Criminal Proceeds and Instruments Bill 2005, no 279-1, cl 3.

52 See Patricia Loughlan "Equity and the Proceeds of Crime" (1991) 2 CICJ 106.

53 Australian Law Reform Commission Confiscation that Counts: A Review of the Proceeds of Crime Act 1987 (ALRC 87, Sydney, 1999) 29.

$54 \quad R v$ Brough [1995] 1 NZLR 419 (CA) [Brough]. 
was not a form of punishment. ${ }^{55}$ The decision relied upon the idea that an offender has no right to property obtained unlawfully, so it cannot be viewed as punishment to take this property away. In light of the similarities between the CPIB and the PCA, it is unlikely that the courts would take a different view of the CPIB.

In the United Kingdom, the Proceeds of Crime Act 2002 (UK) contains a civil forfeiture regime called "civil recovery", and defendants have attempted to have it classified as a criminal proceeding in order to gain additional protections under the Human Rights Act 1998 (UK). While there has been no authoritative statement yet by the Court of Appeal or the House of Lords, there are judgments from lower courts that may reveal the potential approach to be taken in New Zealand towards the CPIB.

An early challenge to the Proceeds of Crime Act 2002 (UK) came in the case of Director of the Assets Recovery Agency $v$ Walsh. ${ }^{56}$ In Walsh the approach to classification was derived from a decision of the European Court of Justice. ${ }^{57}$ An approach similar to that in Wigglesworth was adopted, with the legislative classification of the proceeding not considered determinative, and a focus upon the public nature of the proceeding and its effects on the defendants. The decisive factor was that the civil recovery is not aimed at punishing defendants, only at recovering the proceeds of serious criminal offending. ${ }^{58}$ Under the Walsh approach, like the second limb of the Wigglesworth test, the purpose becomes the crucial aspect in determining the classification of the civil forfeiture regime of the CPIB.

Ultimately it is difficult to imagine the New Zealand courts taking a different approach than Brough or Walsh in defining the purpose of the civil forfeiture regime. This means that for the purposes of the NZBORA, proceedings under the CPIB would probably be classified as civil and so the protections affirmed in sections 24 to 26 of the NZBORA would not apply.

\section{Substance of Civil Forfeiture}

Despite its civil form, I argue that the civil forfeiture regime of the CPIB is criminal in its substance. While the CPIB does not aim to punish offenders, the effect for the defendant is very similar to a criminal conviction. The civil forfeiture regime not only seeks to take away profits of criminal offenders, but also seeks to reinforce the norms of public order contained in the criminal law. The basis for the forfeiture is that there has been a breach of the criminal law, and the confiscation of the profit endeavours to discourage such breaches. It is only the State that can undertake a civil forfeiture proceeding, as it is public interests that the State is seeking to represent.

\footnotetext{
55 Brough, above n 54, 423 Tompkins J for the Court.

56 Director of the Assets Recovery Agency v Walsh [2004] NIQB 21 [Walsh].

57 See Engel $v$ The Netherlands (No 1) (1976) 1 EHRR 647, 678.

58 Walsh, above n 56, para 19 Coughlan J.
} 
The public interest in the maintenance of public order signals the criminal substance of the civil forfeiture regime of the CPIB.

In the eyes of the layperson, a defendant subject to a successful civil forfeiture order will attract all the stigma of a criminal conviction, even if this is not, in a legal sense, the outcome of a civil forfeiture order. The formal outcome for the defendant, while not imprisonment, is a financial loss, the same as for many convicted criminal defendants. But while in the civil law monetary penalties are routinely employed, under the civil forfeiture regime there is still a link to the underlying criminal offending. Within the community, the defendant will face the full stigma of having been convicted of a crime.

The concepts of unjust enrichment and restitution as rationales for civil forfeiture do not explain the approach taken towards civil forfeiture under the CPIB. The CPIB is not an in rem proceeding, because under a Profit Forfeiture Order the property may have been lawfully acquired, but the confiscation still takes effect because of serious criminal activity by the individual concerned. ${ }^{59}$

These features illustrate that the civil forfeiture regime of the CPIB is criminal in its substance, because of its effect on defendants. Though the CPIB's claimed purpose is not punishment, it has the effect of punishing defendants for criminal behaviour. The civil forfeiture regime takes elements of the criminal paradigm into its formal position within civil proceedings. The civil forfeiture regime of the CPIB therefore represents a new type of State-invoked sanction, where public law rights are asserted through private law remedies in the form of a punitive civil sanction. ${ }^{60}$

\section{CIVIL FORFEITURE AND THE MINIMUM STANDARDS OF CRIMINAL PROCEDURE}

This section examines how the operation of the CPIB goes against the "principles of justice", due to the absence of procedural protections for defendants facing punitive civil sanctions, like civil forfeiture. I analyse three rights contained within the NZBORA, which encapsulate long-held principles of the common law: the burden and standard of proof for criminal defendants, retrospective punishment and double jeopardy. I then consider how the civil forfeiture regime of the CPIB affects these rights, and how its "civil" classification makes such effects possible while still maintaining compliance with the NZBORA.

\section{A The Burden and Standard of Proof}

Under the CPIB the principal benefit to law enforcement is the lower standard of proof required to achieve confiscation of assets under civil forfeiture, compared to the PCA which requires a criminal offence proven beyond a reasonable doubt. The civil forfeiture regime of the CPIB allows

59 Anthony Kennedy "Justifying the Civil Recovery of Criminal Proceeds" (2004) 12 JFC 8, 11.

60 Danny Friedman "Disguising the Elephant: Civil Recovery and the End of Criminal Law" (Matrix Chambers Seminar, London, 15 December 2001) 6. 
someone to be subject to a sanction which is criminal in substance, even though a reasonable doubt may exist as to their guilt.

Defendants charged with a criminal offence have the right to be presumed innocent and the State is given the burden of proving them guilty beyond a reasonable doubt under section 25(c) of the NZBORA. ${ }^{61}$ However, being subject to civil forfeiture proceedings under the CPIB is not considered being charged with a criminal offence. The justification for the right is that an individual should not be subject to State coercion unless the State, with all its resources, is able to prove to a high degree of certainty that there has been a breach of the law. In effect, the CPIB violates this right. As the civil forfeiture regime is criminal in substance, it is inappropriate that the protections provided to criminal defendants do not extend to individuals who face confiscation of property under the civil forfeiture regime.

This illustrates the greatest problem with civil forfeiture. While criminal offending requires proof beyond reasonable doubt, under the civil forfeiture regime of the CPIB criminal offending is not required to be proven to this level. With a civil standard of proof a defendant may face the full impact of State coercion on the basis that they are probably guilty, ${ }^{62}$ even though a reasonable doubt exists as to their guilt. The CPIB explicitly states that to undertake civil forfeiture the court only needs to be satisfied on the balance of probabilities. ${ }^{63}$ Until the Court of Appeal decision in Spellacey $v$ Solicitor-General, ${ }^{64}$ the law in New Zealand required that "when a serious allegation is made in civil proceedings ... the degree of probability must be commensurate with the seriousness of the allegation." ${ }^{16}$ A higher standard of proof would therefore have been required in civil forfeiture proceedings, which by their very nature require satisfaction that there has been significant criminal activity. Following Spellacey, where serious allegations, including criminal ones, are made in the course of civil proceedings, the allegation will only need to be proven on the balance of probabilities.

The civil forfeiture regime can also breach the presumption of innocence, in that even though defendants have only had assets confiscated and no criminal conviction has been obtained, they are still subject to the stigma associated with one. Were they genuinely to be presumed innocent, it would be inconsistent to subject them to this stigma. Within the community this side effect is almost

61 This interpretation is adopted from the Supreme Court of Canada's decision in $R v$ Wholesale Travel Group [1991] 3 SCR 154.

62 Liberty (the National Council for Civil Liberties) Proceeds of Crime: Consultation on Draft Legislation (May 2001) 22, available at <http://www.liberty-human-rights.org.uk> (last accessed 9 October 2006).

63 Criminal Proceeds and Instruments Bill 2005, no 279-1, cls 47, 53, 55 and 61.

64 Spellacey v Solicitor-General (2003) 21 CRNZ 140 (CA) [Spellacey]. See generally Richard Mahoney "Evidence" (2005) NZ Law Rev 69.

65 Mahoney, above n 64, 69 
certain to operate, though it is admittedly not anomalous in the civil law. ${ }^{66}$ The principal objection to using the balance of probabilities as the standard of proof is that defendants will suffer the effects of confiscation on the basis that they are probably guilty. ${ }^{67}$

Civil forfeiture under the CPIB also introduces a reverse onus provision. The Director or prosecutor does not need to prove the value of the benefit that the defendant has derived from serious criminal activity. ${ }^{68}$ Once the Director or prosecutor has discharged the burden of proving that there has been serious criminal activity, the onus is upon the defendant to prove that the amount allegedly derived is too high. This reverse onus provision has particularly harsh consequences. Confiscation under the PCA, or criminal forfeiture under the CPIB, requires a criminal conviction before any confiscation. This means that the defendant has a chance to defend themselves with all of the protections usually afforded to criminal defendants. However, for civil forfeiture under the CPIB there is only a civil standard of proof satisfied before the reverse onus is engaged, resulting in a significantly harsher outcome for defendants. This lower standard of proof operates as a much lower threshold before the severity of the reverse onus provision takes effect.

\section{B Retrospective Punishment}

Retrospective punishment is forbidden under section 26(1) of the NZBORA. While there is no question of the CPIB criminalising activity which was not previously criminal, as the underlying serious criminal offending required for civil forfeiture reflects longstanding offences, it does increase the severity of punishment, which is covered by section $25(\mathrm{~g})$ of the NZBORA. Profit Forfeiture Orders cover all serious criminal activity within the previous seven years, ${ }^{69}$ effectively imposing a harsher punishment upon individuals that did not exist at the time which the criminal activity took place. The prohibition on retrospective punishment does not apply to the civil forfeiture regime, as it is not a criminal proceeding. The criminal forfeiture regime does change the penalty imposed, but it does not breach section $25(\mathrm{~g})$ because it is not harsher than the effect of the provisions of the PCA. ${ }^{70}$ Civil forfeiture, on the other hand, would undoubtedly be in conflict with section $25(\mathrm{~g})$ were it covered.

In the United Kingdom, the Proceeds of Crime Bill 2001 was amended to include limitation provisions for proceedings under the Bill, due to the difficulty in adducing evidence to defend

66 Kennedy, above n 59, 18.

67 Liberty, above n 62, 22.

Criminal Proceeds and Instruments Bill 2005, no 279-1, cl 54.

69 Criminal Proceeds and Instruments Bill 2005, no 279-1, cl 5.

70 Val Sim and Allison Bennett, Crown Counsel, Crown Law Office, to the Attorney General "Criminal Proceeds and Instruments Bill - Bill of Rights Vetting" (10 June 2005) Letter 6 (Obtained under Official Information Act 1982 Request to the Ministry of Justice). 
historical criminal allegations. This is a similar rationale to that justifying a limitation period in civil proceedings. ${ }^{71}$ This does not address the same issue that sections $25(\mathrm{~g})$ and 26(1) of the NZBORA tackle, as those sections focus more upon the fairness of imposing a punishment on individuals which is greater than when they committed the offences, rather than the ability of the defendant to adduce evidence for their defence. It is the former principle which the CPIB breaches.

\section{Double Jeopardy}

The interrelationship between criminal and civil law, and the application of the principle of double jeopardy under both the Crimes Act 1961 and section 26(2) of the NZBORA, have been fiercely debated in New Zealand, with the Court of Appeal setting out the extent of the protection in Daniels $v$ Thompson. ${ }^{72}$ The Court of Appeal made it clear that double jeopardy protection under section 26(2) does not extend to "punishment outside the ambit of the criminal process." 73

The ability of the Director or prosecutor to undertake civil forfeiture proceedings is explicitly maintained in the CPIB regardless of whether there has been a prior criminal prosecution, even where there has been an earlier unsuccessful prosecution. ${ }^{74}$ There has been significant litigation in the United States on the application of the principle of double jeopardy to civil forfeiture statutes. The Supreme Court of the United States has indicated that civil forfeiture does not invoke the protection because the action is against the property and not against the individual, ${ }^{75}$ relying on the distinction between in rem and in personam forfeiture. ${ }^{76}$ This distinction is not relied upon in New Zealand, as Profit Forfeiture Orders are clearly an action in personam, made against any property belonging to the defendant. The civil forfeiture regime of the CPIB avoids the application of section 26(2) of the NZBORA through its classification as a civil proceeding. So while a breach of the rule of double jeopardy is prevented by the civil classification, the CPIB does, like the Proceeds of Crime Act 2002 (UK), "breach it in spirit". ${ }^{77}$ Despite an acquittal a defendant can effectively still be punished civilly, something the Court of Appeal recognised as inappropriate as a matter of policy in Daniels $v$ Thompson. ${ }^{78}$ It may impose a number of practical difficulties upon defendants, as there are significant investigative powers granted under the CPIB which can compel defendants to

\footnotetext{
71 Andrew McGee Limitation Periods (4 ed, Sweet \& Maxwell, London, 2002) 16.

72 Daniels $v$ Thompson [1998] 3 NZLR 22 (CA).

73 Daniels $v$ Thompson, above n 72, 34 Henry J.

74 Criminal Proceeds and Instruments Bill 2005, no 279-1, cl 16.

75 See United States v Ursery (1996) 518 US 267

76 Kennedy, above n 59, 19.

77 Kennedy, above n 59, 19.

78 Daniels $v$ Thompson, above n 72, 47 Henry J.
} 
provide certain information, ${ }^{79}$ and which could then in turn be used to assist police and prosecutors in a subsequent criminal investigation and prosecution.

The way that these rights are proven ineffective by the civil forfeiture regime of the CPIB illustrates the effectiveness of punitive civil sanctions. As identified above, the CPIB is able to fulfil many functions of the criminal law through its civil forfeiture regime that would be inconsistent with the NZBORA if proceedings under it were classified as criminal. Because the civil forfeiture regime is criminal in its nature and substance, it effectively defeats the rationale of many of these protections by having a severe punitive effect, but without any of the usual protections.

\section{A LEGITIMATE USE OF A PUNITIVE CIVIL SANCTION?}

\section{A The Legitimate Role of Punitive Civil Sanctions}

Mann advocates the use of punitive civil sanctions to fulfil the under-enforcement of certain aspects of the criminal law, such as the lack of prosecutions for fraud and corporate crime. ${ }^{80}$ It is inappropriate to deal with some criminal behaviour using the criminal law, because the high procedural protections granted to defendants make their prosecution difficult. Furthermore, it may not be desirable to deal with minor infractions of the law using the severe sanction of a criminal prosecution. Mann argues that routine sanctioning should be achieved through punitive civil sanctions, which are capable of a broader reach because of their less serious penalty and their less burdensome procedural setting. ${ }^{81}$ An example of a punitive civil sanction in the New Zealand context is the civil enforcement of insider securities trading laws by the Securities Commission under the Securities Markets Act 1988. Civil forfeiture under the CPIB is not however a legitimate role for punitive civil sanctions. Proponents of the CPIB have clearly identified the rationale for introducing the CPIB as being to deal with the problem of serious criminal offending by organised crime. The potential impacts upon defendants are extremely harsh. These are not the "less serious" sanctions for which punitive civil sanctions are justified.

Mann argues that "criminal law has a distinctive normative role, and it should be reserved for the most damaging wrongs and most culpable defendants." 82 But the Police argue that members of organised crime groups are the most culpable defendants, and commit the most damaging wrongs. ${ }^{83}$ How then can punitive civil sanctions be appropriate? The CPIB represents a pragmatic approach to serious problems created by organised crime and drug dealing, but does it sacrifice too much principle in order to achieve its objectives?

79

80

81

82

83

Criminal Proceeds and Instruments Bill 2005, no 279-1, subpart 7

Mann, above n 2, 1872.

Mann, above n 2, 1862.

Mann, above n 2, 1863

"Hitting at the Heart of the Justice System" (January/February 2005) Police News 15. 


\section{B Dealing with Organised Crime}

The greater convenience to law enforcement officials as a result of the introduction of a punitive civil sanction like the CPIB comes at a cost to effectiveness in dealing with organised crime and drug dealing. In New South Wales there has been a perception that the civil forfeiture regime introduced by the Criminal Assets Recovery Act 1990 (NSW) did not operate to deter organised crime and drug dealers, and was merely operating as a tax upon serious criminal activity. ${ }^{84}$ This perception arose because the majority of civil forfeiture proceedings were resolved by settlement. Intuitively, most defendants would only settle if it were for an amount less than the maximum they would forfeit if the claim succeeded, therefore leaving them to keep a portion of their wealth. Only assets are confiscated, so they are left to continue their criminal activity in freedom, albeit less wealthy than before.

Without the possibility of civil forfeiture under the CPIB the only sanction available to prosecutors is criminal prosecution. The Ministry of Justice identified the possibility that the Police might concentrate their attentions upon civil forfeiture proceedings rather than criminal ones because of the lower procedural protections given to defendants, in cases where they may have attempted a criminal prosecution were civil forfeiture not an option. ${ }^{85}$ The risk of this was supposed to be dealt with by the diversion of all decisions on civil forfeiture away from the Police or prosecutors to the independent role of the Director of Criminal Proceeds Confiscation. There is, however, no provision to ensure that a criminal prosecution will be undertaken where there is a reasonable chance of success, rather than relying solely upon civil forfeiture under the CPIB. Were such a provision included in the CPIB it could reinforce the message that criminal prosecution and conviction is the preferred method by which the State deals with serious criminal offending.

The only real protection from abuse of the separate civil proceedings is the independent decision-making powers granted to the Director. ${ }^{86}$ One wonders to what extent decisions will be made independently when such a high level of cooperation is required between the Police, prosecutors and the Director to deal effectively with organised crime. Faced with the option of the more comprehensive and onerous procedural requirements of a criminal prosecution compared to those in a civil forfeiture proceeding, it would be understandable if law enforcement chose to deal with the problem civilly. This would in turn divert police resources away from the investigation of the crimes which organised crime groups have committed, to the investigation of assets for civil forfeiture proceedings.

84 Young, above n 4, 15.

85 Young, above n 26, 24.

86 Criminal Proceeds and Instruments Bill 2005, no 279-1, cl 86. 
Under the New South Wales legislation a separate recovery body equivalent to the Director was set up because of a feared conflict of interest between "the primary responsibility to exercise the prosecutorial discretion in the public interest and the recovery of profit." ${ }^{17}$ This conflict of interest undermines the principal objective of the CPIB to reduce criminal activity by organised crime groups. A similar approach in New Zealand is being adopted with the separate role of the Director and a separate agency, but considering cooperation will no doubt take place between the various law enforcement agencies, one is left wondering if this will be sufficient.

\section{Public Faith in the Justice System}

Civil forfeiture in the absence of complementary criminal sanctions threatens to undermine public faith in the justice system in two ways. In attempting to maintain the lower procedural protections given to civil proceedings, the civil forfeiture regime does not purport to be an adjudication of guilt. However, there is a formal pronouncement by the court that on the balance of probabilities the defendant has benefited from serious criminal activity. This presents a confusing image to the layperson. The civil forfeiture proceedings have resulted in an adjudication of guilt, a penalty imposed and property confiscated. Yet the defendant, proven to have committed serious criminal activity, has not been imprisoned. It is at this sort of defendant, for whom criminal activity can be proven on the balance of probabilities but not beyond a reasonable doubt, that the CPIB is principally aimed.

The CPIB allows civil forfeiture subsequent to a failed criminal prosecution for the same offence. ${ }^{88}$ This too must present a conceptually confusing image to the layperson. In the criminal prosecution the defendant may be found not guilty, yet with civil forfeiture they are still punished. This illustrates how those who are "probably guilty", but not guilty beyond a reasonable doubt, are not convicted. The stark contrast could lead to dissatisfaction with the criminal justice system and the special protections granted to defendants in it. This may in turn lead to attacks on other special protections granted to criminal defendants. It is difficult to see that the public appetite for justice will be met by the CPIB as it favours pragmatism over principle to such a degree, and in the eyes of the public will leave serious criminal offenders not properly punished.

\section{CONCLUSIONS AND RECOMMENDATIONS}

After the initial review of the PCA, the Ministry of Justice recommended a number of peripheral changes to the PCA to make it more effective, and to deal with some of the criticisms levelled against it. ${ }^{89}$ The PCA would be maintained as a conviction-based regime to remove the profits from serious criminal offending, once the offending had been proven in court. I consider that this is the

87 Young, above n 4, 27.

88 Criminal Proceeds and Instruments Bill 2005, no 279-1, cl 16.

89 Young, above n 4, 22-25. 
correct approach, as only through the prerequisite of a criminal conviction can any system be sufficiently certain that a defendant warrants the imposition of a penalty which is criminal in substance.

The principal criticisms of the PCA are those commonly made against the justice system in general. It is difficult for the prosecution to obtain a conviction in order to impose a punishment. But this difficulty serves an important purpose, and the introduction of civil forfeiture serves as an attack upon it. Rather than abandoning the requirement of a conviction before punishment, a better approach may be to focus upon the difficulties identified with the PCA, and attempt to remedy them in order to cause the least possible interference with individuals' rights. There will always be an inherent conflict between protecting the innocent, and punishing those who keep themselves distant from the actual criminal offending. This is a fundamental problem and it cannot be dealt with easily. The CPIB does not provide a ready answer.

The CPIB presents a new way of tackling criminal activity, moving away from a use of the criminal law towards the use of civil proceedings to fulfil many of the same objectives. As a punitive civil sanction, civil forfeiture under the CPIB is able to avoid the application of many of the protections contained within the NZBORA. This means that there are significant risks for an individual's rights, with no special protection from State coercion. Individuals can be subject to confiscation of property even where a reasonable doubt exists as to their guilt. The punishment imposed by civil forfeiture is greater than what could be imposed at the time of the criminal offending, and the ability to pursue criminal prosecutions in addition to civil forfeiture may mean that a subsequent criminal defence could be prejudiced by defending the civil proceeding.

Punitive civil sanctions do have a role to play in the criminal law. They are a useful tool when used for more minor infractions that may otherwise go unpunished. They are not suitable, however, for use in the case of the most serious offending, such as organised crime or drug dealing, because they are criminal in substance without sufficient protections in their application. They are unable to be effective as genuine criminal punishments, due to the need to maintain their classification and appearance as a civil proceeding for the purposes of avoiding the NZBORA protections for criminal defendants.

Confiscation of the proceeds of crime within the criminal justice process is the best way of avoiding the problems faced by using civil proceedings to achieve a criminal law objective. This ensures that fewer people have to suffer the traumatic ordeal of defending and opening themselves to scrutiny against allegations of criminal activity or the confiscation of their property by the State. 
